\title{
Pandemi dan Ruang Kelas Dunia Maya
}

\author{
Nunung Nurfajri Ainun*, \\ * Teknologi Pendidikan, Universitas Negeri Makassar. \\ Email: nunungnurfajriainun1@gmail.com
}

\section{ABSTRACT}

This article purposes and describe about classrooms situation that move through online class, at the primary school level in Bone district. The situations that force everyone to adapt with a network learning system, giving a different experiences and meanings in each school, parent and students. This research article conducted at two elementary schools in Bone district, for two weeks starting on March 29 to April 12, 2020 with descriptive qualitative research methods, the informants were chosen based on snowball techniques, to five informants. The informant is considered to be able to give an idea about virtual classrooms were in the pandemic. Interviews conducted by chatting and in direct interview. Research data is also supported by chat in 'virtual classrooms', and literature. The results showed that there were two groups of virtual classes during this pandemic, namely, 1) Parents as the center, in cyberspace classes during this pandemic, The parent becomes the center of learning process, because the teacher communicates to students through the parent intermediary. 2) Parent become leaders where parent act as a teachers who teach and explain material to their children, 3) Parent become associate, where teaching and learning activities are still carried out by the teacher through learning videos, video links to voice notes, so that parent only act as student associate. These findings, of course, are influenced with the facilities and infrastructure prepared by the school. School support, creativity and teacher initiative and the role of parent became the movers of the virtual world class during this pandemic.

Keywords: home school, pandemic, elementary school, virtual classrooms, parents.

\begin{abstract}
ABSTRAK
Artikel ini bertujuan memberikan gambaran tentang situasi ruang kelas yang berpindah melalui daring, pada tingkat sekolah dasar di kabupaten Bone. Situasi yang memaksa setiap orang beradaptasi dengan sistem belajar berjejaring, memberikan pengalaman dan pemaknaan yang berbeda pada tiap sekolah, orang tua dan siswa. Artikel ini didasarkan pada penelitian yang dilakukan pada dua sekolah dasar di kabupaten Bone, selama dua minggu dimulai pada tanggal 29 Maret s/d 12 April 2020 dengan metode penelitian deskriptif kualitatif, informan dipilih berdasarkan teknik snowball, kepada lima orang informan. Informan tersebut dianggap sudah bisa memberikan gambaran bagaimana ruang kelas virtual di masa pandemi. Wawancara dilakukan melalui chat dan secara langsung. Data penelitian juga didukung oleh obrolan di 'ruang kelas virtual', dan kepustakaan. Hasil penelitian menunjukkan ada tiga kelompok kelas virtual di masa pandemi ini yaitu, 1) Orang tua sebagai pusat, dalam kelas dunia maya di masa pandemi ini, Orang tua lalu menjadi pusat proses pembelajaran, sebab guru berkomunikasi kepada siswa melalui perantara orang tua. 2) Orang tua sebagai Pemimpin dimana orang tua bertindak sebagai guru yang mengajar dan menjelaskan materi kepada anak, 3) Orang tua sebagai Pendamping, dimana kegiatan belajar mengajar masih dilakukan oleh guru melalui, video pembelajaran, link video hingga voice note, sehingga orang tua hanya bertindak sebagai pendamping siswa. Temuan tersebut, tentunya dipengaruhi oleh
\end{abstract}


sarana dan prasarana yang disiapkan oleh sekolah. Dukungan sekolah, kreativitas serta inisiatif guru dan peran orang tua menjadi penggerak dari kelas dunia maya di masa pandemi ini.

Kata Kunci: sekolah dirumah, pandemi, sekolah dasar, kelas virtual, orang tua.

\section{PENDAHULUAN}

Dunia saat ini dihadapkan dengan masalah yang sama yaitu Virus Covid-19 atau Corronavirus yang berawal dari kasus pertama di Kota Wuhan, China pada tanggal 17 November 2019. Setelah itu covid-19 juga memasuki negara-negara lainnya termasuk Indonesia. Dikutip dari laman harian kompas (31/03/2020), covid-19 masuk di Indonesia pada tanggal 2 maret 2020 pada kasus pertama yang ada di Jakarta dan pada akhir bulan maret telah mencapai 1.528 orang yang positif dan hal tersebut masih berkembang pada saat memasuki awal bulan april. Di indonesia penyebaran covid19 sangat cepat, dengan adanya kondisi terseut membuat pemerintah untuk lebih mempersiapkan hal-hal yang kemungkinan terjadi termasuk di dalam dunia pendidikan. Berkaitan dengan hal tersebut maka pemerintah dalam hal ini mendikbud Nadiem Makarim mengeluarkan surat edaran (SE) nomor 36962/MPK.A/HK/2020 mengenai pembelajaran secara daring dan bekerja dari rumah dalam rangka pencegahan penyebaran covid-19 hal ini diakses di laman Kemendikbud.ri. Dengan adanya pandemi telah mengubah pola pembelajaran secara. Proses pembelajaran sebelumya dilaksanakan dengan cara tatap muka dan sekarang proses pembelajaran berubah menjadi sistem pembelajaran jarak jauh atau daring (dalam jaringan). Sejalan dengan hal itu internet memegang peranan penting dalam proses pembelajaran ini, dan pengguna internet di indonesia juga semakin meningkat menurut survei yang dilakukan oleh Asosiasi Peyelenggara Jaringan Internet Indonesia (APJII) pada tahun 2018 ditemukan bahwa terdapat 171,17 juta jiwa di Indonesia yang memakai internet (Katadata, 2019). Dengan kebijakan yang dikeluarkan oleh pemerintah untuk study from home dan work from home maka penggunaan internet di indonesia hingga 2019 diprediksi sampai 175,4 juta orang dengan penetrasi mencapai $64 \%$ yang artinya dari total 272,1 juta populasi di indonesia $64 \%$ telah terkoneksi internet (Agustina.S, 2020).

Proses belajar dengan cara daring atau $e$ learning dinilai sangat baik untuk menghambat proses penyebaran wabah pandemi covid-19 yang tersirat di dalam surat edaran pemerintah. Keadaan ini menuntut agar sekolah dan perguruan tinggi harus siap untuk menjalani perubahan sistem pembelajaran tersebut. Dengan kata lain sekolah harus memberikan layanan yang dapat diakses untuk pembelajaran daring. Dalam jurnal penelitian Mustofa, dkk (2019) mengatakan bahwa pembelajaran daring adalah sistem pembelajaran jarak jauh yang menggunakan bantuan teknologi. Pembelajaran daring merupakan pembelajaran tanpa tatap muka secara langsung antara guru maupun siswa, tetapi hal itu dilakukan secara online baik dilakukan melalui video confrence, e-learning atau distance learning (Hakiman, 2020). Pembelajaran daring ini diharapkan dapat menjadi sarana yang efektif menggantikan proses belajar di sekolah dengan cara study from home, yang memanfaatkan model belajar daring. Proses pembelajaran daring dilaksankan semua tingkat pendidikan termasuk di sekolah dasar (SD). Konsep belajar daring yang terkait digitalisasi menjadikan guru harus paham terlebih dahulu tentang pembelajaran daring bagi anak-anak yang sifatnya mendidik sekaligus mengajar. Selain itu guru-guru juga didorong untuk memahami makna digitalisasi dan pemanfaatan teknologi untuk membantu dalam proses pembelajaran. Selain guru, orang tua pun harus beradaptasi menjadi guru di rumah. Hal ini disebabkan metode belajar di rumah tidak hanya berpusat pada aspek kognitif, tetapi orang tua juga harus memberikan pendidikan yang bermakna dan beradptasi dengan model pendampingan belajar. Dalam jurnal penelitian yang dilakukan oleh Rizal, dkk (2018) mengenai sistem kelas virtual dan pengelolaan pembelajaran berbasis 3-dimensional virtual yang mengatakan bahwa yang hanya membedakan antara pembelajaran kelas kovensial dan kelas virtual yaitu sarana yang dimanfaatkan untuk pembelajaran konvensional memanfaatkan ruangan kelas untuk melaksanakan pembelajaran, sedangkan kelas virtual hanya memanfaatkan jaringan internet untuk melakukan proses pembelajaran.

Hasil observasi awal pada akhir bulan maret ternyata masih banyak sekolah dasar 
khusunya di kabupaten Bone saat ini yang belum mengelola sistem belajar daring sesuai dengan konsep pembelajaran daring. Guru hanya memanfaatkan aplikasi Whatsapp sebagai sarana untuk mengirim tugas kepada orang tua siswa. Hal itu menjadi permasalahan dalam pelaksanaan pembelajaran daring di sekolah dasar karena tidak adanya proses pembelajaran yang dilakukan oleh guru.

Prawiradilaga (Anggraeni dan Sole, 2018) dalam jurnal penelitian tentang E-Learning Moodle, Media Pembelajaran Fisika Abad 21, Pembelajaran daring merupakan bagian dari Integrated Learning Design Framework (ILDF) karena memiliki ciri khas yang sama yaitu beorientasi pada proses belajar kelas virtual, memunculkan masalah mengenai batasan waktu dan geografis, dan menyusun pembelajaran mandiri dengan materi yang ada pada kelas tatap muka.

Dalam jurnal hasil penelitian yang dilakukan oleh Wirawan, dan Wahyudi (2019) mengatakan bahwa e-learning dapat dimanfaatkan dengan cara guru dapat membuat suatu kelas dalam aplikasi $e$-learning, selain itu dapat juga membuat suatu forum diskusi untuk mendiskusikan sebuah pokok bahasan yang akan disampaikan dan dibahas bersama dengan siswa. Keberhasilan pemanfaatan e-learning dilihat dari interakasi antara pendidik dan peserta didik

Beberapa penelitian telah dilakukan mengenai pembelajaran daring atau e-learning, Rahmatia, dkk (2017) tentang pengaruh media elearning terhadap hasil belajar matematika siswa kelas IV SD adapun hasil penelitiannya yaitu terdapat sebuah pengaruh media e-learning untuk mencapai hasil belajar matematika yang baik. Fatmawati, dkk (2015) tentang aplikasi elearning sekolah dasar (SD) Muhammadiyah 2 kauman Surakarta untuk menambah interaksi guru dan siswa, adapun hasil penelitiannya yaitu aplikasi e-learning disusun berdasarkan perancangan sistem yang mendukung kegiatan belajar mengajar dengan maksud untuk menambah interaksi antara guru dan siswa dengan mengedepankan konsep student center learning. Isman (2017) tentang pembelajaran moda dalam jaringan adapun hasil penelitiannya yaitu pembelajaran moda dalam jaringan dilakukan dengan memiliki keleluasan waktu belajar, dan dapat berinteraksi baik dengan pendidik dan pebelajar.
Berdasarkan penelitian sebelumnya dan hasil observasi yang dilakukan maka menarik perhatian peneliti untuk mengkaji mengenai gambaran pembelajaran daring yang dilakukan di masa pandemi covid-19, pada tingkat sekolah dasar di Kabupaten Bone.

\section{METODE}

Penelitian ini merupakan penelitian kualitatif yang menggunakan pendekatan deskriptif, yang menggambarkan keadaan tanpa rekayasa peneliti. Penelitian ini dilakukan selama dua minggu dimulai pada tanggal 29 Maret s/d 12 April 2020. Pada penelitian ini sumber data diperoleh dari guru, siswa, dan orang tua siswa di sekolah dasar yang bertindak sebagai sumber data primer. Sumber data tersebut diperoleh dengan menggunakan teknik snowball sampling. Sedangkan sumber data sekunder yang digunakan bersumber dari literature, jurnal, dan buku serta sumber lain yang relevan. Data dikumpulkan dengan menggunakan teknik wawancara melalui chat, dan wawancara langsung serta didukung dengan bukti atau dokumentasi obrolan kelas virtual di masa pandemi.

Data diolah dengan menggunakan model dari Miles dan Huberman (dalam Rijali, 2018) pengolahan data dilakukan dengan: (1) Reduksi, yaitu merangkum, memilih, dan memfokuskan pada hal-hal penting. Sehingga memberikan gambaran yang jelas. (2) Penyajian data yang disajikan dalam bentuk naratif. (3) Penarikan kesimpulan, setelah menjabarkan berbagai data yang telah diperoleh, peneliti membuat kesimpulan dari hasil suatu penelitian.

Data yang diperoleh melalui wawancara dalam penelitian ini dianalisis menggunakan analisis deskriptif kualitatif. Sumber data utama merupakan data wawancara yang menjadi bahan analisi data dalam penelitian ini. Analisis data dimulai dengan melakukan wawancara. Setelah melakukan wawancara peneliti membuat transkip akhir dengan menuliskan kata-kata atau kalimat sesuai hasil wawancara dengan informan, dan setelah itu peneliti membuat reduksi data yang mengambil data yang sesuai dengan konteks penelitian. 


\section{HASIL DAN PEMBAHASAN}

Hasil

Untuk mengetahui kondisi awal pembelajaran daring di masa pandemi ini hal yang penulis lakukan adalah pengamatan secara tidak langsung mengenai pembelajaran daring yang dilaksannakan pada masa pandemi ini. Setelah itu penulis mendaptkan data awal sekaligus mengenal lebih jauh tentang pembelajaran daring yang dilaksanakan oleh anak SD di masa pandemi dengan cara mewawancarai siswa, orang tua siswa, dan guru pada sekolah dasar di Kabupaten Bone yang dianggap representatif. Hal ini dikarenakan banyaknya siswa dan orang tua siswa yang mengeluh mengenai pelaksanaan pembelajaran daring ini yang tidak sesuai dengan konsep pembelajaran daring umumnya.

Dalam mengatasi pembelajaran daring di sekolah dasar Kabupaten Bone salah satunya SD Negeri 13 Cellu yang menerapkan dan memanfaatkan aplikasi whatssapp sebagai media yag digunakan dalam proses pembelajaran. media yang digunakan dalam pembelajaran. Adapun cara penggunaan whatsapp dalam pembelajaran yaitu (1) guru membuat sebuah grup bersama dengan orang tua; (2) setiap jam mata pelajaran guru menanyakan keadaan siswanya dan memastikan bahwa siswa tersebut tetap di rumah, setelah itu guru memberikan tugas untuk menggantikan proses belajar di sekolah,; (3) orang tua mendampingi dan memberitahukan kepada anaknya untuk mengerjakan tugas yang diberikan oleh guru; (4) orang tua mengirimkan dokumentasi dan bukti pengerjaan anaknya; (5) setelah itu guru menilai dengan menggunakan peneliaan kualitatif. Namun selain itu ada juga sekolah dasar yang memanfaatkan platform dalam proses pembelajaran yaitu Sekolah Dasar Ilmu Teknologi Rabbani (SDIT Rabbani) Kabupaten Bone. Di sekolah tersebut memanfaatkan bebrapa media dalam proses pembelajaran, dalam berkomunikasi dengan orang tua siswa guru tetap menggunakan aplikasi whatsapp dalam pembelajaran, namun yang berbeda dengan kebanyakan sekolah di kabupaten bone yaitu cara guru mengajar memiliki banyak varian dalam hal ini yang penulis teliti yaitu guru. Adapun cara proses pembelajaran daring di SDIT Rabbani yaitu; (1) guru awalnya membuat sebuah grup whatsaap untuk berkomunikasi dengan orang tua sisiwa; (2) setiap jam mata pelajaran guru memulai berkomunikasi dengan orang tua, menanyakan keadaan siswa; (3) guru memberikan tugas kepada siswa, namun sebelumnya sering ada pengantar dari guru mengenai tugas yang diberikan baik berupa video maupun voice note; (4) guru sering memberikan sebuah link video, atau guru membuat video pembelajaran singkat untuk dipelajari maupun dipraktekkan, misalnya mata pelajaran penjaskes; (5) orang tua melakukan pendampingan saat anak belajar, dan tetap mengirimkan dokumentasi belajar baik berupa video maupun foto, dan bukti pengerjaan tugas kepada gurunya; (6) setelah pelajaran selesai, guru mengirimkan form melalui via google form untuk orang tua mengisi laporan aktivitas harian anaknya; (7) penilaian yang diberikan yaitu penilaian kualitatif untuk meningkatkan semangat siswa dalam belajar. Untuk pemberian ulangan harian dan UTS guru memanfaatkan google form desain ulangannya pun hampir sama dengan pembelajaran konvensional namun yang membedakan hanya cara pengisiannya.

Hasil wawancara secara keseluruhan mengenai pembelajaran daring pada tingkat SD di Kabupaten Bone ditunjukkan pada table di bawah ini.

Tabel 3.1 Hasil Observasi di Sekolah Dasar Negeri dan Swasta

\begin{tabular}{cl}
\hline Perihal & \multicolumn{1}{c}{ Hasil Observasi } \\
Media yang digunakan & $\begin{array}{l}\text { Secara umum media yang digunakan untuk proses pembelajaran daring } \\
\text { yaitu memanfaatkan aplikasi whatsapp, Namun yang membedakan dengan }\end{array}$ \\
& $\begin{array}{l}\text { sekolah swasta yang ada di Kabupaten Bone yaitu guru seringkali } \\
\text { memanfaatkan platform pembelajaran untuk melakukan ujian atau }\end{array}$ \\
& $\begin{array}{l}\text { ulangan harian, misalnya menggunakan platform google classroom untuk } \\
\text { mengevaluasi pengetahuan siswa yang didampingi oleh orang tua. }\end{array}$ \\
\hline Proses Pembelajaran & $\begin{array}{l}\text { Sebagian besar proses pembelajaran hanya dilakukan dengan pemberian } \\
\text { tugas dikirimkan ke whatsapp grup atau mengirimkan satu persatu ke }\end{array}$ \\
\hline
\end{tabular}




\begin{tabular}{ll}
\hline & $\begin{array}{l}\text { orang tua siswa mengenai tugas yang diberikan. Dalam proses pengerjaan } \\
\text { tugas sebagian besar dilakukan sesuai dengan jam pelajaran di sekolah. }\end{array}$ \\
\hline $\begin{array}{l}\text { Pembelajaran daring } \\
\text { pada pembelajaran }\end{array}$ & $\begin{array}{l}\text { Dalam pembelajaran daring yang berbasis praktek, misalnya mata } \\
\text { pelajaran penjaskes. Pada saat wawancara mengenai pembelajaran } \\
\text { berbasis praktek }\end{array}$ \\
$\begin{array}{l}\text { penjaskes yang dilaksanakan atau tidak dilaksanakan dalam pembelajaran } \\
\text { daring. Sebagian sekolah melakukan dan sebagian juga tidak } \\
\text { melakukannya. }\end{array}$ \\
\hline Cara Penilaian & $\begin{array}{l}\text { Cara penilaian yang digunakan guru dengan cara penilaian kualitatif, } \\
\text { misalnya pekerjaan kamu bagus sekali, mohon dipertahankan. }\end{array}$ \\
\hline Cara pendampingan dalam \\
orang tua & $\begin{array}{l}\text { Sebagian besar orang tua selalu mendampingi anaknya dalam } \\
\text { mengerjakan tugas, dan orang tua yang berperan menggantikan guru di }\end{array}$ \\
& sekolah. Siswa mengerjakan tugas yang diberikan guru, dan orang tua \\
& siswa mendampingi dan memberikan dokumentasi kepada guru saat anak \\
& belajar. Setelah itu orang tua mengirimkan hasil tugas anak kepada guru \\
& yang mengajar.Namun yang dikeluhkan orang tua yaitu kurangnya \\
pengantar yang diberikan oleh guru dalam pembelajaran daring sehingga \\
orang tua sering kebingunan mengenai tugas yang diberikan kepada \\
anaknya.
\end{tabular}

Pembelajaran daring di sekolah dasar kabupaten Bone, berdasarkan penelitian ini terbagi atas dua yaitu: (1) Hanya memanfaatkan whatsapp sebagai media pemberian tugas, tanpa ada proses penjelasan dari guru. Pada model ini, guru hanya memberikan tugas berdasarkan LKS atau buku panduan, selanjutnya siswa mengerjakan dan yang memegang peranan adalah orang tua pendamping anak. Model ini, menjadikan orang tua sebagai pengajar utama, yang harus menjelaskan kepada anak. (2) Model kedua, selain memberi tugas melalui whatsapp, guru tetap meberikan penjelasan kepada siswa melalui video sederhana, video pembelajaran yang sudah jadi, hingga voice note. Selain itu guru juga mengirimkan laporan aktivitas harian siswa kepada orang tua. Hal tersebut menjadikan orang tua tidak lagi bertindak penuh sebagai pengajar, tapi sebagai pendamping.

\section{Pembahasan}

Berdasarkan hasil penilitian yang telah dipaparkan di atas, pada model pertama yang hanya menggunakan whatsapp sebagai media pemberian tugas tanpa adanya proses penjelasan maka pembelajaran daring dalam model ini dikatakan belum optimal dilakukan. Hal ini diperkuat oleh pendapat menurut C.L Dillon, C.N Gunawardena, dan Leidner (dalam Pangondian dkk., 2019) diantaranya; (1) teknologi, pengaturan jaringan harus memungkinkan terjadi pertukaran sinkronisasi dan asinkronisasi dan siswa harus memiliki akses yang mudah; (2) karakteristik pengajar yang memainkan peran sentral dalam efektivitas pembelajaran secara daring, bukan sebuah teknologi yang penting tetapi penerapan instruksional teknologi dari pengajar yang menentukan efek pada pembelajaran; (3) karakteristik siswa, bagi siswa yang tidak memiliki keterampilan dasar dan disiplin diri yang tinggi dapat melakukan pembelajaran yang lebih baik dengan metode yang disampaikan secara konvesional, sedangkan siswa yang memiliki kecerdasan dan kedisiplinan yang tinggi dapat melakukan pembelajaran daring. Dari ketiga faktor penentu kesuksesan pembelajaran daring tidak terlaksana pada model pertama hasil penelitian. Hal ini diperoleh gambaran pembelajaran daring untuk kalangan anak SD pada model pertama membutuhkan peran guru sebagai sentra dalam proses pembelajaran daring yang dapat menerapkan instruksional teknologi, sehingga terjadi proses pembelajaran yang optimal bukan hanya pemberian tugas yang diberikan. Akan tetapi di dalam model kedua pada hasil penilitian ketiga faktor tersebut terlaksana baik dilihat dari segi teknologi, karakteristik guru, maupun karakteristik siswa. 
Dari dua model pembelajaran daring yang dilaksanakan di rumah, orang tua mempunyai peran sebagai berikut:

\section{Orang Tua sebagai Pusat}

Proses pembelajaran di masa pandemi ini orang tua sebagai pusat pembelajaran, dimana guru hanya berkomunikasi dengan orang tua mengenai materi dan tugas yang akan diberikan oleh siswa. Oleh karena itu orang tua yang berperan sebagai pusat informasi dari guru ke siswa dan juga sebagai pusat proses pembelajaran anaknya.

\section{Orang Tua sebagai Pemimpin}

Orang tua berperan sebagai pemimpin dalam proses pembelajaran dalam artian orang tua menggantikan peran guru sebagai pengajar yang menjelaskan materi kepada anaknya. Hal itu terjadi dikarenakan guru hanya memberikan tugas kepada siswa tanpa adanya pengantar atau materi yang diberikan sebelum mengerjakan tugas. Oleh karena itu peran orang tua sangat penting dalam proses pembelajaran daring yang membantu anak agar tetap melaksanakan proses pembelajaran di rumah.

\section{Orang Tua sebagai Pendamping}

Dalam masa pandemi ini orang tua juga berperan sebagai pendamping anak dalam proses pembelajaran. Hal tersebut terjadi dikarenakan proses pembelajaran daring guru tetap melaksanakan proses pembelajaran baik melalui video pembelajaran, membagikan link video pembelajaran tambahan, hingga mengirimkan pesan voice note kepada orang tua siswa untuk didengarkan kepada siswanya. Orang tua sebagai pendamping karena orang tua tetap berkomunikasi dengan guru dan melakukan instruksi dari guru agar proses pembelajaran anaknya tetap berjalan lancar.

Temuan tersebut, tentunya dipengaruhi oleh sarana dan prasarana yang disiapkan oleh sekolah. Dukungan sekolah, kreatifitas serta inisisatif guru dan peran orang tua menjadi penggerak dari kelas dunia maya di masa pandemi ini.

\section{SIMPULAN DAN SARAN}

\section{Simpulan}

Pembelajaran daring adalah pembelajaran yang menggunakan teknologi dan akses internet dalam mengikuti pelajaran baik dalam model sinkronisasi maupun asinkronisasi. Pembelajaran di sekolah dasar di kabupaten Bone terdapat dua model pembelajaran daring yang dilakukan, diantaranya; (1) model pertama guru hanya menggunakan whatsapp sebagai media pemberian tugas tanpa adanya proses pembelajaran, sehingga orang tua berperan utama sebagai pengajar di rumah dan (2) model kedua, selain pemberian tugas melalui whatsapp guru juga memberikan pengantar atau penjelasan mengenai materi yang akan dibahas, baik berupa video pembelajaran singkat, hingga voice note. Orang tua berperan sebagai pendamping saat anak belajar daring di rumah.

\section{Saran}

Berdasarkan hasil penelitian maka dapat disarankan agar dapat dalam melakukan proses pembelajaran daring harus memperhatikan halhal yang mendukung terjadinya proses pembelajaran daring dengan optimal, guru perlunya memberikan proses pembelajaran kepada anak usia sekolah dasar, bukan hanya pemberian tugas yang diberikan.

\section{DAFTAR RUJUKAN}

Agustina, S. Ketika Semua Harus Dilakukan di Rumah. URL: https://kompas.id/baca/riset/2020/04/01/keti ka-semua-harus-dilakukan-di-rumah/. Diakses pada tanggal 03 April 2020.

Anggraeni, D. M., \& Sole, F. B. (2018). ELearning Moodle, Media Pembelajaran Fisika Abad 21. Jurnal Penelitian Dan Pengkajian Ilmu Pendidikan: E-Saintika, 1(2), 57-65.

Annur, C. M. Survei APJII: Penetrasi Pengguna Internet di Indonesia Capai 64,8\%. URL: https://katadata.co.id/berita/2019/05/16/sur vei-apjii-penetrasi-pengguna-internet-di- 
indonesia-capai-648. Diakses Pada tanggal 03 April 2020.

Fatmawati. I. W., Siswanti. S., \& Nugroho. D. (2016). Aplikasi E-Learning Sekolah Dasar (Sd) Muhammadiyah 2 Kauman Surakarta Untuk Menambah Interaksi Guru Dan Siswa. Jurnal Teknologi Informasi Dan Komunikasi (TIKomSiN), 3(2), 10-18.

Hakiman. 2019. Pembelajaran Daring. URL: https://iainsurakarta.ac.id $/ \% \mathrm{EF} \% \mathrm{BB} \% \mathrm{BFpembelajaran}$ -daring/. Diakses pada tanggal 04 April 2020.

Isman, M. (2017). Pembelajaran Moda dalam Jaringan (Moda Daring). The Progressive and Fun Education Seminar, 586-588.

Mendikbud. SE Mendikbud: Pembelajaran Secara Daring dan Bekerja dari Rumah untuk MencegahPenyebaran Covid-19. URL:

https://www.kemdikbud.go.id/main/blog/20 20/03/se-mendikbud-pembelajaran-secaradaring-dan-bekerja-dari-rumah-untukmencegah-penyebaran-covid19. Diakses pada tanggal 01 April 2020.

Mustafa, M. I., Chodhzirin, M., \& Sayekti, L. (2019). Formulasi Model Perkuliahan Daring Sebagai Upaya Menekan Disparitas Kualitas Perguruan Tinggi. Walisongo Journal of Information Technology: 1(2), 151-160.

Pangondian, R. A., Santosa, P. I., \& Nugroho, E. (2019). Faktor - Faktor Yang Mempengaruhi Kesuksesan Pembelajaran Daring Dalam Revolusi Industri 4.0. Seminar Nasional Teknologi Komputer \& Sains (SAINTEKS).

Rahmatia, M., Monawati, \& Darnius, S. (2017). Pengaruh Media E-Learning Terhadap Hasil Belajar Matematika Siswa Kelas IV SDN 20 Banda Aceh. Jurnal Ilmiah Pendidikan Guru Sekolah Dasar, 2(1), 212-227.

Rijali, A. (2018). Analisis Data Kualitatif. Jurnal
Alhadharah: 17(33), 81-95.

Rizal, A., Adam, R. I., \& Sulaswati. (2018). Sistem Kelas Virtual dan Pengelolaan Pembelajaran berbasis 3- Dimensional Virtual World. Jurnal Edukasi dan Penelitian Informatika: 4(2), 132-140.

Shalihah, N. F. Update Corona di Indonesia: 1.528 Positif, Dua Provinsi Nol Kasus. URL:

https://www.kompas.com/tren/read/2020/0 3/31/193000265/update-corona-diindonesia--1.528-positif-dua-provinsi-nolkasus. Diakses pada tanggal 01 April 2020.

Wirawan, A. W., \& Wahyudi, W. (2019). ELearning Equipment in Learning Processat Vocational High School. Social, Humanities, and Educational Studies (SHEs): Conference Series, 1(2), 61. 